\title{
A naming convention for atmospheric organic aerosol
}

\author{
B. N. Murphy ${ }^{1,2}$, N. M. Donahue ${ }^{3}$, A. L. Robinson ${ }^{4}$, and S. N. Pandis ${ }^{3,5}$ \\ ${ }^{1}$ Department of Meteorology, Stockholm University, Stockholm, Sweden \\ ${ }^{2}$ Department of Applied Environmental Science, Stockholm University, Stockholm, Sweden \\ ${ }^{3}$ Department of Chemical Engineering, Carnegie Mellon University, 5000 Forbes Ave, Pittsburgh, \\ Pennsylvania 15213, USA \\ ${ }^{4}$ Department of Mechanical Engineering, Carnegie Mellon University, 5000 Forbes Ave, Pittsburgh, \\ Pennsylvania 15213, USA \\ ${ }^{5}$ Department of Chemical Engineering, University of Patras, Patra, Greece
}

Correspondence to: S. N. Pandis (spyros@ andrew.cmu.edu)

Received: 13 September 2013 - Published in Atmos. Chem. Phys. Discuss.: 15 November 2013

Revised: 16 April 2014 - Accepted: 20 April 2014 - Published: 12 June 2014

\begin{abstract}
While the field of atmospheric organic aerosol scientific research has experienced thorough and insightful progress over the last half century, this progress has been accompanied by the evolution of a communicative and detailed yet, at times, complex and inconsistent language. The menagerie of detailed classification that now exists to describe organic compounds in our atmosphere reflects the wealth of observational techniques now at our disposal as well as the rich information provided by state-of-the-science instrumentation. However, the nomenclature in place to communicate these scientific gains is growing disjointed to the point that effective communication within the scientific community and to the public may be sacrificed. We propose standardizing a naming convention for organic aerosol classification that is relevant to laboratory studies, ambient observations, atmospheric models, and various stakeholders for air-quality problems. Because a critical aspect of this effort is to directly translate the essence of complex physicochemical phenomena to a much broader, policy-oriented audience, we recommend a framework that maximizes comprehension among scientists and non-scientists alike. For example, to classify volatility, it relies on straightforward alphabetic terms (e.g., semivolatile, SV; intermediate volatility, IV; etc.) rather than possibly ambiguous numeric indices. This framework classifies organic material as primary or secondary pollutants and distinguishes among fundamental features important for science and policy questions including emission source, chemical phase, and volatility. Also useful is the addition of an alphabetic suffix identifying the volatil-
\end{abstract}

ity of the organic material or its precursor for when emission occurred. With this framework, we hope to introduce into the community a consistent connection between common notation for the general public and detailed nomenclature for highly specialized discussion. In so doing, we try to maintain consistency with historical, familiar naming schemes, unify much of the scattered nomenclature presented in recent literature, reduce the barrier of comprehension to outside audiences, and construct a scaffold into which insights from future scientific discoveries can be incorporated.

\section{Introduction}

Atmospheric aerosols have documented, although not fully understood, impacts on public and environmental health as well as the climate system (Seinfeld, 2004; Seinfeld and Pandis, 2006; Stocker et al., 2013). As a result, researchers have worked for decades to quantify these impacts and to report their findings back to the public in hopes of improving societal outcomes through better-informed decision-making. Without a doubt, scientific understanding of atmospheric aerosol in general and specifically organic aerosol has grown considerably over the past two or three decades (Seinfeld and Pankow, 2003; Seinfeld, 2004; Fuzzi et al., 2006; Donahue et al., 2009). The atmospheric aerosol research community has invented and refined a large number of analytical techniques and conceptual models to characterize the observed complexity of the corresponding pollutants and their precursors. 
As understanding of aerosols has been refined so has the language used to describe it. With the application of each new instrument, our ability to sort and classify pollutants according to previously undetectable properties (e.g., oxidation state) (Zhang et al., 2011) has emerged, or our ability to resolve familiar properties has increased (e.g., at one time separating particulate matter with a diameter smaller than $2.5 \mu \mathrm{m}$ from the larger particles was considered challenging; now the scanning particle size magnifier enables detection of particles smaller than $2 \mathrm{~nm}$ ) (Kulmala et al., 2013).

Concurrent with such advances, new labels typically arise to identify new categories or properties in order to facilitate discussion of any differences among them: different societal impacts, different emission sources, etc. As a result, the field has developed several useful schemes for classifying organic aerosol (OA) that are logical, self-consistent, and effective (see for example Seinfeld and Pankow, 2003; Pöschl, 2005; Fuzzi et al., 2006; Donahue et al., 2009; Mohr et al., 2009; Ervens et al., 2011; Zhang et al., 2011). But when viewed as a whole, the landscape of jargon, operationally defined terms, and subtle caveats in OA research nomenclature has become imposing even for scientific experts and insurmountable to stakeholders.

This resulting complexity certainly reflects the underlying complexity in the OA system. Myriad sources contribute significantly to the OA burden, complicating the analysis of formation, growth, and removal (Seinfeld and Pandis, 2006; Wallace and Hobbs, 2006). Wood burning (residential, prescribed outdoor, forest fires, etc.), electricity generation, manufacturing, personal transportation, solvent use, shipping (by boat, train, or aircraft), cooking, emission of volatile vapors from plants, sea spray, and other activities all contribute to OA burden at urban, regional, and/or global scales (Kanakidou et al., 2005; Mohr et al., 2009; Hallquist et al., 2009). After emission, these compounds are susceptible to a wealth of oxidation processes that often significantly alter their structure and properties (Hallquist et al., 2009). For these reasons, defining a succinct, self-consistent naming convention is challenging. An effective naming framework should be straightforward and readily understood by non-experts. However, it should also be detailed and flexible to communicate as much information as possible about the origin and chemical nature of OA material. Before proposing such a naming convention, we review past attempts to classify OA over the last two decades and the specific challenges that have emerged.

Initially, OA was described by just two classifications: primary organic aerosol (POA) and secondary organic aerosol (SOA). POA described presumably non-volatile and inert OA emitted in the particle phase from a source, while SOA described material beginning its atmospheric lifetime as a volatile gas and, after oxidation and condensation, forming condensable (typically semivolatile) organic aerosol (Seinfeld and Pandis, 2006). In this original framework POA and SOA had different sources, volatility and chemical charac- teristics, and this simple categorization was sufficient to describe the then-understood complexity of OA (Pandis et al., 1993). Most chemical transport models (CTMs) using this simple framework predicted a majority of the OA in the atmosphere to be POA due to its nonvolatile and nonreactive nature (Chung and Seinfeld, 2002; Gaydos et al., 2007; Karydis et al., 2007).

As new observational techniques (e.g., aerosol mass spectrometry: AMS) emerged, studies such as Zhang et al. (2005) found it useful to distinguish between OA that is comprised of highly reduced molecules (hydrocarbon-like OA: HOA) and $\mathrm{OA}$ that is consistent with highly oxygenated compounds (oxygenated OA: OOA). Ambient OA was found to contain significantly more OOA than HOA with OOA fractional contributions routinely greater then $90 \%$ (Zhang et al., 2005; DeCarlo et al., 2010; Crippa et al., 2013). Following the common assumption that HOA generally aligned with POA and OOA with SOA, some traditional models were predicting SOA/OA ratios that were extremely low compared to observations (Volkamer et al., 2006; Shrivastava et al., 2008). Results from the European Monitoring and Evaluation Programme (EMEP) model, using higher SOA yields, showed higher SOA/OA ratios in suburban/rural areas of Europe ( 70-80\%) (Andersson-Sköld and Simpson, 2001; Simpson et al., 2007). Still, those results were consistent with the lower bound estimates of the very large OOA/HOA ratios measured by the AMS at urban, suburban, and remote sites during later campaigns (Kulmala et al., 2011; Crippa et al., 2013).

Several pieces of evidence emerged to help explain this discrepancy. The traditional model assumed that the effects of oxidation on organic compounds could be accounted for by considering only the first generation of reactions between organic molecules and atmospheric oxidants (e.g., hydroxyl radical, ozone, and nitrate radical) (Pandis et al., 1993; Griffin et al., 1999; Strader et al., 1999). It is now clear from smog-chamber experiments that semivolatile OA components formed from the oxidation of atmospherically relevant molecules like xylene (Loza et al., 2012), $\alpha$-pinene (Salo et al., 2011; Tritscher et al., 2011; Donahue et al., 2012; Henry et al., 2012), and $\beta$-caryophyllene (Alfarra et al., 2012) continue to react with atmospheric oxidants. Whether this continued oxidation leads to a net enhancement or loss of ambient OA material is unclear due to the number and complexity of interactions that occur.

A second piece of evidence addressing the disagreement between the traditional conceptual model of POA/SOA and AMS observations of highly oxygenated material was reinforced when Lipsky et al. (2005), Grieshop et al. (2009a) and Robinson et al. (2007) argued that POA emissions are substantially semivolatile when diluted to ambient levels. Observations of semivolatile partitioning were not new; Fraser et al. $(1997,1998)$ measured the concentration of semivolatile species in both the vapor and particle phases from ambient samples. The net transfer to the gas phase reduces the 
influence of hydrocarbon-like, or reduced organic species in the conceptual model. Moreover, these gas-phase species are susceptible to rapid oxidation that can lead to condensation of secondary products back to the particle phase (Presto et al., 2010; Jathar et al., 2012). Communicating the nature of this highly dynamic OA material in an effective way is problematic. This material was originally accounted for as POA, but then it underwent a chemical change. Donahue et al. (2009) called this material oxygenated POA (OPOA), a term that identifies both the phase of the material upon emission as well as its chemical history. Both of these pieces of information are useful for scientific applications.

The added complexity associated with treating POA gasparticle partitioning and the effects of SOA and POA multigenerational oxidation led Donahue et al. (2006) to develop the volatility basis set (VBS) framework to organize all of these species into one continuum based on their volatility. In this scheme, organic material can be assigned to a volatility bin (lumped surrogate of many species with similar volatility) upon emission and can then be moved to higher or lower volatility in this space to account for the effects of oxidation. Chemical transport models have implemented this framework and explored the sensitivity of OA mass predictions to uncertainties in volatility of emissions and effects of oxidation (Lane et al., 2008; Hodzic et al., 2010; Murphy and Pandis, 2010; Fountoukis et al., 2011; Murphy et al., 2011; Ahmadov et al., 2012; Bergström et al., 2012). Observations of organic aerosol volatility have been refined as well through the use of gas chromatography (Isaacman et al., 2011; Presto et al., 2012; May et al., 2013a, b; Chan et al., 2013) and thermodenuder methods (Baltensperger et al., 2005; An et al., 2007; Saleh et al., 2008; Grieshop et al., 2009a, b; Hildebrandt et al., 2009; Huffman et al., 2009). Because of the physical importance of volatility to gas-particle partitioning and the widespread attention volatility has received, it makes sense to anchor a proposed scheme to this property. However, there are some additional complexities that must be considered first in order to achieve a naming convention that is useful for both detailed scientific research and regulatory implementation.

It is also common practice to classify OA by its sources rather than its properties. Distinguishing between "anthropogenic" and "biogenic" OA, aSOA and bSOA respectively, is a common approach to assess the contribution of humans to atmospheric particles. Biomass-burning organic aerosols (BBOA) are emitted by natural forest fires, prescribed burning practices, biofuel use, and residential wood combustion among other sources. BBOA compounds are often classified separately due to the difficulty in assigning them to either anthropogenic or biogenic sources (Simoneit, 2002; Fast et al., 2009). Aqueous-phase SOA (aqSOA) is formed from the dissolution of organics in cloud droplets, followed by reaction in the aqueous phase and finally evaporation of the liquid water (Blando and Turpin, 2000). Recent work has shown that even volatile compounds like glyoxal and methylglyoxal can react in the aqueous phase and contribute to this source of organic aerosol (Carlton et al., 2008; Lim et al., 2010; Ervens et al., 2011; Myriokefalitakis et al., 2011) and the SOA products of these processes may be important on global scales (Liu et al., 2012). These distinctions (aSOA, bSOA, BBOA and aqSOA) are useful in discussing and reporting model results but are often difficult to identify using observational techniques.

In recent years, field observations have led to the emergence of several new classifications for OA. For example, analysis of AMS data has identified the importance of specific sources like cooking OA (cOA), marine OA (mOA), and traffic OA (tOA) (Mohr et al., 2009; Ovadnevaite et al., 2011). Individual organic compounds or molecular markers are often commonly used to apportion ambient OA to sources (Schauer et al., 1996). Much work has also been accomplished in using ${ }^{14} \mathrm{C}$ concentrations to attribute $\mathrm{OA}$ to fossil (fOA) and non-fossil (nfOA) sources (Szidat et al., 2006; Simpson et al., 2007; Schichtel et al., 2008; Marley et al., 2009). The influence of water-soluble organic carbon (WSOC) has been assessed throughout the world with the particle into liquid sampler (PILS) (Sullivan et al., 2004; Hennigan et al., 2009).

Current ambient air-quality and emissions standards are, with respect to organic compounds, reflective of the traditional POA/SOA conceptual model. For example the US EPA has historically required operators of stationary sources to report only emissions of VOCs and total particulate matter through assessment method 5 (Fed. Regist., 1971). Assessment method 5 dictated that particulate matter be withdrawn from the source collected on a glass fiber filter maintained at a temperature of $120 \pm 14^{\circ} \mathrm{C}$. The particulate matter mass was defined as any material that condensed at or above the filtration temperature. By encouraging methods 201A and 202 (Fed. Regist., 2010), the agency acknowledged the importance of capturing both filterable (particulate mass at stack temperature without dilution) and condensable particulate matter (particulate mass at $30^{\circ} \mathrm{C}$ without dilution), respectively. Method 201A built upon method 5 by introducing a $\mathrm{PM}_{2.5}$ cyclone before the collection train and specified a cutoff temperature $\left(30^{\circ} \mathrm{C}\right)$ for stack operation. If this cutoff temperature was exceeded, the "stack tester" was required to complete method 202: capture condensable particulate matter in a dry impinger, extract the material with hexane and water, dry the sample, and weigh it. Unfortunately, these methods are known to have serious positive and negative artifacts, precisely because semivolatile compounds tend to be both mobile and sticky. Dilution sampling equipment and techniques (Hildemann et al., 1989; Lipsky and Robinson, 2005; England et al., 2007; Li et al., 2011) have been developed over the last 30 years and are regarded as the most realistic method available for mimicking short-range atmospheric processing (Lee, 2010). Shrivastava et al. (2006), Donahue et al. (2009), and Robinson et al. (2010) argued that measurements should be taken at a range of dilution ratios to characterize the volatility distribution of a sample 
and its likely behavior at ambient conditions. These measurements should include high-dilution ratios above 200:1 and most importantly reach low concentrations similar to ambient conditions. However, the magnitude of necessary dilution depends on the OA mass loading in the emissions plume near the source. The same authors also pointed out interferences that could exist because partitioning of emissions to the real environment will depend on background OA concentrations. Because of these complications, the line between POA and SOA blurs and careful thought must be put into applying a naming convention to the reporting and enforcement of OA standards in air-quality management.

Systematic classifications for organic compounds have been proposed in the past. Donahue et al. (2009) recommended separating species by volatility in line with the VBS framework. Fuzzi et al. (2006) focused instead on distinguishing between 11 sources including biogenic, fossil fuel combustion, open biomass burning, and sea spray among others. That work also acknowledged, though, that classifications by source and those by property should begin to converge as more is learned about $\mathrm{OA}$ in general.

We propose an organized naming convention for communicating both OA sources and properties. The convention allows systematic inclusion or omission of detail depending on context and the target audience. In Sect. 2, we describe the framework itself, which is fundamentally based on the VBS conceptual model with compounds classified by their volatility. In Sect. 3, we describe extensions to this framework that incorporate the detailed OA classes that have become widely used with increased use of AMS, gas chromatography, and radiocarbon field observations. Finally in Sect. 4, we show how the proposed framework applies to methods used in airquality management.

\section{Proposed nomenclature}

The proposed classification system describes intensive properties and emission sources of atmospheric organic compounds by relying on three components combined in the following syntax:

[current volatility] $-[\text { source][root name }]_{\text {phase }}-[$ initial volatility $]$,

where the current volatility of the classification indicated by an alphabetic capitalized prefix, the source and root name indicated by acronyms currently used in the field, and the initial volatility of the species upon emission (or its precursor if it is a secondary species) indicated by a lowercase alphabetic suffix.

The root name (Table 1) along with the phase subscript concisely describes several aspects of the organic species of interest. This core of the framework is the most familiar to the atmospheric aerosol community. It begins with designation of the species as a primary $(\mathrm{P})$ or secondary $(\mathrm{S})$ constituent followed by a token identifying all of the organic material
(OA) or just the material from carbon (OC). Here, we define pollutant material as primary if it has not undergone a chemical change in the atmosphere (i.e., it could have changed phase). Pollutant material is secondary if it has been chemically changed in the atmosphere. The specific phase of the material is then identified with a subscripted word (or letter for shorthand): particle (p), vapor (v), or total (t). One can easily identify other phases as well (see Table 2). We finally propose one critical addendum to this scheme. If no phase subscript is provided (e.g., OA, POC, SOA), the acronym is assumed to refer only to condensed-phase material (i.e., no subscript "p" is needed). This addition effectively clarifies discussions with the non-aerosol and non-scientific community when the distinction of phase causes more confusion than clarity and is anyway subordinate to broader issues.

The source modifier preceding the root name identifies the emission source with terminology and abbreviations commonly used in the research community (Table 3 ). Anthropogenic (a) and biogenic (b), biomass burning (bb), cooking (c) and marine (m) categories are all subjects of ongoing work and important on local, regional, and global scales. Further, it is quite straightforward to combine these identifiers to further resolve material. For example, "abbOA" would distinguish biomass burning organic aerosol as a result of anthropogenic activity from "bbbOA", biomass burning organic aerosol from natural activities.

We have chosen to omit the common modifier "aq" for identifying organic aerosol formed during reaction in an aqueous phase. While this formation pathway is an area of intensive and exciting study, our scheme focuses on attributes of OA relevant to its state at emission or current state, not on the formation process. Hypothetically, confusion arises when OA compounds formed via gas-phase reaction react in a dry particle with compounds formed via aqueous-phase reaction to form new products. Is this product material also aqSOA? More information is needed regarding the importance of this formation pathway, and the fate of its products in order for it to be accurately incorporated into the proposed scheme. Meanwhile, the phase subscript offers a method to identify hydrophilic organic material currently in an aqueous phase.

The alphabetic volatility prefix (Table 4) uses five broad categories to classify organic species by their current volatility (when measured in the lab or field, written to model output, etc.). Extremely low volatility (ELV-), low volatility (LV-), semivolatile (SV-), intermediate volatility (IV-) and volatile (V-) all describe organic compounds along a spectrum of effective saturation concentration at $298 \mathrm{~K}$. Donahue et al. (2006) recommended separating volatility by one order of magnitude in effective saturation concentration, or $C^{*}\left(\mu \mathrm{g} \mathrm{m}^{-3}\right)$, and this work follows that framework. Each volatility category includes several $C^{*}$ bins and the boundaries of each classification have been chosen as the base-10 logarithmic average of the representative saturation concentrations (Table 4). For example, the boundary in effective saturation concentration between semivolatile and 
Table 1. Examples of root names for OA classifications.

\begin{tabular}{|c|c|}
\hline Term & Description \\
\hline OA & $\begin{array}{l}\text { Organic aerosol (primary }+ \text { secondary). It consists of all of the atoms in the constituent } \\
\text { molecules including carbon, oxygen, hydrogen, nitrogen, and sulfur, etc. }\end{array}$ \\
\hline POA & Primary organic aerosol. This material has not undergone a chemical reaction. \\
\hline SOA & $\begin{array}{l}\text { Secondary organic aerosol. This material has undergone a chemical reaction in the } \\
\text { atmosphere in either the particle or vapor phase. }\end{array}$ \\
\hline $\mathrm{OC}$ & $\begin{array}{l}\text { Organic carbon (primary }+ \text { secondary). It consists of just the carbon contribution } \\
\text { to the organic material. }\end{array}$ \\
\hline POC & Primary organic carbon. This material has not undergone a chemical reaction. \\
\hline SOC & $\begin{array}{l}\text { Secondary organic carbon. This material has undergone a chemical reaction in the } \\
\text { atmosphere in either the particle or vapor phase. }\end{array}$ \\
\hline
\end{tabular}

Table 2. Examples of phase subscripts for OA classifications.

\begin{tabular}{|c|c|c|}
\hline Subscript & Examples & Description \\
\hline [no subscript] & $\mathrm{OA}, \mathrm{OC}$ & The acronym specifies only the condensed-phase material. \\
\hline particle (p) & $\mathrm{OA}_{\text {particle }}, \mathrm{OA}_{\mathrm{p}}, \mathrm{OC}_{\text {particle }}, \mathrm{OC}_{\mathrm{p}}$ & $\begin{array}{l}\text { Condensed-phase material. This is completely interchangeable and synonymous with } \\
\text { omitting the phase subscript. }\end{array}$ \\
\hline vapor $(\mathrm{v})$ & $\mathrm{OA}_{\mathrm{vapor}}, \mathrm{OA}_{\mathrm{V}}, \mathrm{OC}_{\mathrm{vapor}}, \mathrm{OC}_{\mathrm{V}}$ & Material currently in the vapor phase regardless of the phase state of its precursor. \\
\hline total $(\mathrm{t})$ & $\mathrm{OA}_{\text {total }}, \mathrm{OA}_{\mathrm{t}}, \mathrm{OC}_{\text {total }}, \mathrm{OC}_{\mathrm{t}}$ & Total material in all phases. \\
\hline organic (o) & $\mathrm{OA}_{\text {organic }}, \mathrm{OA}_{\mathrm{o}}, \mathrm{OC}_{\text {organic }}, \mathrm{OC}_{\mathrm{o}}$ & $\begin{array}{l}\text { Condensed organic phase material. In other words, material partitioning to the organic phase } \\
\text { (as opposed to the aqueous phase, for example) in a multi-phase condensed system. }\end{array}$ \\
\hline aerosol water (aw) & $\mathrm{OA}_{\text {aerosol water }}, \mathrm{OA}_{\mathrm{aw}}, \mathrm{OC}_{\text {aerosol water }}, \mathrm{OC}_{\mathrm{aw}}$ & $\begin{array}{l}\text { Material hydrophilic enough to partition to the aqueous phase in aerosol particles } \\
\text { suspended in air that is subsaturated with respect to water. }\end{array}$ \\
\hline cloud water (cw) & $\mathrm{OA}_{\text {cloud water }}, \mathrm{OA}_{\mathrm{cw}}, \mathrm{OC}_{\text {cloud water }}, \mathrm{OC}_{\mathrm{cw}}$ & Material absorbed into cloud droplets. \\
\hline glassy (gl) & $\mathrm{OA}_{\text {glassy }}, \mathrm{OA}_{\mathrm{gl}}, \mathrm{OC}_{\text {glassy }}, \mathrm{OC}_{\mathrm{gl}}$ & $\begin{array}{l}\text { Material exhibiting properties of glassy substances such as low diffusivities and long } \\
\text { mixing timescales in the condensed phase. }\end{array}$ \\
\hline semisolid (ss) & $\mathrm{OA}_{\text {semisolid }}, \mathrm{OA}_{\mathrm{ss}}, \mathrm{OC}_{\text {semisolid }}, \mathrm{OC}_{\mathrm{ss}}$ & Similar to glassy. Material that is exhibiting long mixing timescales in the particulate phase. \\
\hline liquid (1) & $\mathrm{OA}_{\text {liquid }}, \mathrm{OA}_{1}, \mathrm{OC}_{\text {liquid }}, \mathrm{OC}_{\mathrm{l}}$ & Material exhibiting high diffusivities and quite short mixing timescales within particles. \\
\hline
\end{tabular}

intermediate-volatility $\mathrm{OA}$ is $C^{*}=10^{2.5}$ or approximately $320 \mu \mathrm{g} \mathrm{m}^{-3}$.

The mapping of each of the semi-quantitative volatility classes to quantitative measures in $C^{*}$ space has been carefully considered. Semivolatile material (SV; $0.32 \mu \mathrm{g} \mathrm{m}^{-3}<C^{*}<320 \mu \mathrm{g} \mathrm{m}^{-3}$ ) partitions significantly to both condensed and vapor phases at OA concentrations relevant for the troposphere. Extremely low volatility (ELV) material on the other hand, has such low-vapor phase levels that it is essentially inaccessible to gas-phase oxidation and experiences no appreciable aging via this route during its atmospheric lifetime. At the other end of the spectrum, volatile material with $C^{*}>3.2 \times 10^{6} \mu \mathrm{g}, \mathrm{m}^{-3}$ is consistent with the legacy acronym, volatile organic compound (VOC), and does not partition at all to the aerosol phase in the atmosphere.

In practice, the definition of effective saturation concentration includes the activity coefficient of each species and so the classification used here may depend on mixing effects. Characterizing these interactions is currently an area of vigorous research, and they may be incorporated into this framework when more thorough understanding has been gained. One approach, similar to the issue of temperature, would be to define reference compositions to further standardize the classification.
The optional suffixes presented in the third column of Table 4 identify the original volatility of the species (if it is primary) or its precursor (if it is secondary) upon emission. If the species is primary, then the suffix will necessarily agree in volatility with the alphabetic prefix; the suffix can thus be omitted, since the species has not undergone a chemical change. If either the prefix or suffix is omitted, it is implied that the acronym identifies the sum of all organic compounds subject to the constraints of any other identifiers in the acronym. For instance, LV-SOA-sv designates lowvolatility particle-phase material formed as reaction products from material emitted in the semivolatile range. Omitting the suffix designates LV-SOA: low-volatility, particlephase species produced by reactions in the atmosphere, derived from precursors with any volatility upon emission. Omitting the prefix from LV-SOA-sv designates SOA-sv: all condensed-phase secondary organic material formed from semivolatile emissions. This could describe, for example, the low-volatility products of oxygenated long-chain hydrocarbons and the very volatile fragments of oxidation processes that occurred.

Table 5 shows examples of terms under the proposed framework and explanations of their contents. The list is not exhaustive; it just illustrates useful possibilities. In general, the framework allows the communication of available 
Table 3. Examples of emission source designations for OA classifications.

\begin{tabular}{cl}
\hline Source & Description \\
\hline $\mathrm{a}$ & $\begin{array}{l}\text { Material from anthropogenic sources } \\
\text { (e.g., aPOA, aSOA, aSOA }\end{array}$ \\
$\mathrm{b}$ & $\begin{array}{l}\text { Material }) \\
\text { (e.g., bSOA, bPOA, bPOA }\end{array}$ \\
& $\begin{array}{l}\text { Material from biomass burning processes } \\
\text { (e.g., bbOA, bbPOA, bbSOA }\end{array}$ \\
$\mathrm{bb}$ & $\begin{array}{l}\text { Material from cooking sources } \\
\text { (e.g., cOA) }\end{array}$ \\
$\mathrm{c}$ & $\begin{array}{l}\text { Material from marine or sea-spray sources } \\
\text { (e.g., mOA) }\end{array}$ \\
$\mathrm{m}$ &
\end{tabular}

information about volatility and source while avoiding confusing and possibly contradicting terminology.

Connecting this approach to the notation proposed by Donahue et al. (2009) is straightforward. The definitions of low volatility, semivolatile and intermediate-volatility organic compounds (LVOC, SVOC, and IVOC, respectively) are exactly the same as in that work. The updated scheme proposed here, though, systematically communicates the OA volatility of precursors from different sources as well. This is particularly important since characterizing the volatility of the most important OA precursors directly informs control strategies to mitigate OA atmospheric concentrations. Moreover, knowledge of how OA volatility evolves in the atmosphere sheds additional light on how concentrations will respond to changing meteorological conditions (for instance, in a changing climate). The scheme more directly distinguishes between OPOA (SV-SOA-sv and LV-SOA-sv), nontraditional SOA (SV-SOA-iv and LV-SOA-iv), and for the first time includes a classification for the low-volatility products of particle-phase reactions involving POA (LV-SOA-lv). It can also be adapted to the large number of specific source categories of OA already mentioned (aSOA, bSOA, bbOA, etc.).

This framework is powerful when applied to developing models of organic compound evolution in the atmosphere. Although primary organic aerosol emitted in the particle phase at low volatility (LV-POA-lv or LV-POA) can contribute significantly to the total OA burden near sources, it is dwarfed in many regions of the atmosphere by contributions from SOA (Zhang et al., 2007). To understand and predict these contributions, one has to understand the processes that transform compounds with relatively high volatility into compounds with volatility low enough to partition significantly to the particle phase. The naming convention proposed here is designed to emphasize the importance of these transformations by identifying the current volatility of material but also the volatility of its precursor upon emission. It becomes conceivable, for instance, for a regionalscale modeling study to report the relative contributions to semivolatile OA (SV-OA) by semivolatile emissions (SVOA-sv), intermediate-volatility emissions (SV-OA-iv), and volatile emissions (SV-OA-v) as a function of season or proximity to major source areas. Although this kind of information has been reported before (Murphy et al., 2010; Tsimpidi et al., 2010; Jathar et al., 2012), imprecise terms like "nontraditional SOA" arose that can be replaced by much more systematic and clear terms when the proposed nomenclature is applied.

Rather than reporting relative contributions of OA from several volatility classes, one could envision reporting a single mass- or molar-weighted volatility. However, the usefulness of such a result is debatable given the strong non-linear dependence of partitioning on volatility. Furthermore, the nature of the proposed naming framework, with its reliance on alphabetic rather than numeric identifiers, is well-suited for communicating broad concepts quickly, rather than relying on the audience's knowledge of the relationships between $\log _{10}\left(C^{*}\right)$ and partitioning.

One can think of other attributes to accommodate with this scheme: for instance, oxidation state (or $\mathrm{O}: \mathrm{C}$ ratio) or functional group as detected by Fourier transform infrared spectroscopy (Russell et al., 2011). Although there is a wealth of data and analysis in recent literature showing the importance and usefulness of these properties, volatility is most directly relevant for gas-particle partitioning under typical atmospheric conditions, which is most relevant for predicting condensed-phase concentrations and societal impacts. Oxidation state can be further incorporated into this scheme if future observations warrant (e.g., if a direct connection to negative human health outcomes is shown).

We further emphasize that use of this scheme does not depend on use of the volatility basis set modeling framework as introduced by Donahue et al. (2006). Other model results or measurements can be easily described with this scheme by estimating the effective volatility of the material to be classified. In the simplest case, one can drop the volatility classification altogether and make use of the phase and source descriptors, while maintaining consistency throughout the community.

\section{Application to laboratory and field measurements}

A versatile naming system must accommodate atmospheric and laboratory observations. The proposed framework specifically identifies the current volatility of organic compounds, a property already measured and reported by many field and lab campaigns (Huffman et al., 2009; Lee et al., 2010; Isaacman et al., 2011; Chan et al., 2013; May et al., 2013a, b). As thermodenuder, dilution, and gas chromatography experiments become more common in the future, it will be critical to report current volatility in a consistent, succinct way. 
Table 4. Prefixes and suffixes used for identifying current and emitted volatility, respectively.

\begin{tabular}{lllrr}
\hline Description & Prefix & Suffix & $\begin{array}{r}\text { Saturation concentration bin center: } \\
298 \mathrm{~K}\left(\mu \mathrm{g} \mathrm{m}^{-3}\right)\end{array}$ & $\begin{array}{r}\text { Saturation concentration range: } \\
298 \mathrm{~K}_{\left(\mu \mathrm{m}^{-3}\right)}\end{array}$ \\
\hline Extremely low volatility & ELV- & -elv & $\leq 10^{-4}$ & $C^{*}<3.2 \times 10^{-4}$ \\
Low volatility & LV- & -lv & $10^{-3}, 10^{-2}, 10^{-1}$ & $3.2 \times 10^{-4}<C^{*}<0.32$ \\
Semivolatile & SV- & -sv & $10^{0}, 10^{1}, 10^{2}$ & $0.32<C^{*}<320$ \\
Intermediate volatility & IV- & -iv & $10^{3}, 10^{4}, 10^{5}, 10^{6}$ & $320<C^{*}<3.2 \times 10^{6}$ \\
Volatile & V- & -v & $\geq 10^{7}$ & $3.2 \times 10^{6}<C^{*}$ \\
\hline
\end{tabular}

The root term OOA and other root terms that have been used for classifying observations are presented in Table 6 . Under this framework, they can be combined with effective saturation concentration prefixes just like the terms from Table 6 , if volatility information is available. Total OOA is approximately equal to total SOA:

$$
\begin{aligned}
\mathrm{OOA} & \approx \mathrm{SOA}=\mathrm{ELV}-\mathrm{SOA}+\mathrm{LV}-\mathrm{SOA} \\
& +\mathrm{SV}-\mathrm{SOA}+\mathrm{IV}-\mathrm{SOA}+\mathrm{V}-\mathrm{SOA},
\end{aligned}
$$

since SOA is distinguished from POA here as material that has been oxidized in the atmosphere. There are exceptions because some primary compounds, notably biomass burning emissions and some biological VOCs, may be partially oxidized upon emission. These compounds are technically POA under the proposed framework.

The prefixes LV and SV, identifying low-volatile and semivolatile species, respectively, have already been used extensively to describe two factors that result from positive matrix factorization (PMF) analysis of aerosol mass spectrometer (AMS) data, LV-OOA and SV-OOA (oxygenated organic aerosol) (Jimenez et al., 2009; DeCarlo et al., 2010). Because the AMS does not measure volatility, it can only be inferred. The original designations were based in part on the association of LV-OOA with (effectively non volatile) sulfate and SV-OOA with (semivolatile) nitrate, including a tendency to increase with decreasing temperature at night (Lanz et al., 2007). In addition, Jimenez et al., (2009) reported the effective saturation concentration of LV-OOA to be at or below $3.2 \mu \mathrm{g} \mathrm{m}^{-3}$ and that of SV-OOA to be between 0.01 and $100 \mathrm{\mu g} \mathrm{m}^{-3}$, while thermal denuder measurements have been used to infer the volatility distribution of the OOA factors (Cappa and Jimenez, 2010; Hildebrandt et al., 2010). These estimates generally align with the volatility cutoffs proposed in the current work, but do not strictly agree. As future studies yield more information about the volatility of LV- and SV-OOA, possibly through volatility-dependent mass spectra observations, these uncertainties can be reconciled with the strict boundaries proposed here. The same is true for the other root terms. The proposed naming framework uses the semi-quantitative lumped effective saturation concentration to distinguish between classes, not qualitative observations.

The flexibility of the proposed framework with regard to describing phase, volatility and source type simultaneously will be very useful once measurement techniques are able to distinguish this information routinely. Any type of organic aerosol observed in the field or lab and described in the literature can be incorporated simply by using it as the root term. This includes OOA, HOA, WSOC, traffic OA (tOA), fossil-fuel OA (fOA), etc. Lab studies will be able to use the suffix this framework includes, as they will generally be able to identify the volatility of the species at the beginning of an experiment. However, field campaigns will have limited or no access to this information. In these cases, the suffix may be omitted and the classification will identify all material as described in Sect. 2.

The treatment of biomass burning OA is a specific example of how the proposed framework can contribute to a more precise description of OA species. BBOA is often classified separately from anthropogenic and biogenic OA in source attribution exercises with the aid of chemical tracers (Simoneit et al., 1999, 2002; Abas et al., 2004) or factor analysis of mass spectra (Zhang et al., 2011 and references therein). Although the latter analysis typically assumes that the BBOA factor represents primary OA emissions from biomass burning events, the distinction between primary and secondary often blurs with mixing and chemical processing as pollutants are transported downwind (Aiken et al., 2010; DeCarlo et al., 2010). Recent studies have investigated the effects of aging on biomass burning emissions (Cubison et al., 2011; Hennigan et al., 2011; Jolleys et al., 2012). The proposed framework easily divides BBOA between particulate matter from primary emissions (bbPOA) and particulate matter formed through secondary processing (bbSOA). Moreover, phase and volatility information can be incorporated if this information is known. When characterizing source contributions or chemical interactions (e.g., with $\mathrm{NO}_{\mathrm{x}}$ ), one can envision the utility of differentiating low-volatility primary biomass burning OA (LV-bbPOA) from semivolatile secondary OA emitted as intermediate-volatility species (SVbbSOA-iv).

Other potentially useful applications of the proposed scheme in the context of field and laboratory observations include (1) OA is captured at an observation station and the chemical composition is measured as a function of volatility with the thermal desorption-gas chromatography-mass spectrometry (TD-GC-MS). When combined with positive 
Table 5. Examples of organic aerosol classifications under the proposed naming convention.

\begin{tabular}{|c|c|c|}
\hline Notation & Description & Emissions \\
\hline ELV-POA-elv or ELV-POA ${ }_{p}$-elv & $\begin{array}{l}\text { Extremely low volatility primary organic aerosol emitted with } \\
\text { extremely low volatility. }\end{array}$ & $\begin{array}{l}\text { Extremely low volatility - } \\
\text { Full partitioning to the particle } \\
\text { phase can be assumed for typi- } \\
\text { cal atmospheric conditions. }\end{array}$ \\
\hline LV-SOA-elv or LV-SOA & $\begin{array}{l}\text { Organic aerosol that is emitted with extremely low volatility and un- } \\
\text { dergoes some chemical change that increases its volatility enough to } \\
\text { partition slightly to the gas-phase under certain conditions. }\end{array}$ & \\
\hline LV-POA-lv & $\begin{array}{l}\text { Primary organic aerosol existing at low volatility and emitted in the } \\
\text { low-volatility range. Has not reacted. }\end{array}$ & $\begin{array}{l}\text { Low volatility - Partitions } \\
\text { mostly to the particle-phase at } \\
\text { atmospheric conditions }\end{array}$ \\
\hline LV-bbOA-lv & Low-volatility emissions from biomass-burning processes & \\
\hline SV-POA-sv or SV-POA & $\begin{array}{l}\text { Semivolatile primary organic aerosol that partitions between the particle } \\
\text { and gas phases at atmospherically relevant conditions }\end{array}$ & $\begin{array}{l}\text { Semivolatile - Partitions } \\
\text { between particle and gas phases } \\
\text { at atmospheric conditions }\end{array}$ \\
\hline SV-POA vapor-Sv or SV-POA $_{\text {vapor }}$ & $\begin{array}{l}\text { Semivolatile primary organic gas that partitions between the particle } \\
\text { and gas phases at atmospherically relevant conditions }\end{array}$ & \\
\hline SV-POA total $^{-S v}$ or SV-POA total & Sum of SV-POA particle and SV-POA & \\
\hline LV-SOA-sv & $\begin{array}{l}\text { Low-volatility, particle-phase products of the oxidation of semivolatile } \\
\text { primary organic compounds }\end{array}$ & \\
\hline OA-sv, $\mathrm{OA}_{\mathrm{p}}$-sv, or $\mathrm{OA}_{\text {particle-sv }}$ & All particle-phase compounds emitted as semivolatile compounds. & \\
\hline $\mathrm{IV}^{-\mathrm{POA}_{\text {vapor-iv }} \text { or IV-POA }} \mathrm{P}_{\mathrm{V}}$ & Intermediate-volatility organic gases that have not reacted & $\begin{array}{l}\text { Intermediate volatility - Parti- } \\
\text { tions mostly to gas phase at at- } \\
\text { mospheric conditions }\end{array}$ \\
\hline SV-SOA-iv & $\begin{array}{l}\text { Semivolatile particle-phase products of the oxidation of intermediate- } \\
\text { volatility gases }\end{array}$ & \\
\hline LV-SOA-iv & $\begin{array}{l}\text { Low-volatility, particle-phase products of the oxidation of intermediate- } \\
\text { volatility gases }\end{array}$ & \\
\hline $\mathrm{SV}_{-} \mathrm{SOA}_{\mathrm{total}^{-}}{ }^{-\mathrm{iv}}$ or $\mathrm{SV}-\mathrm{SOA}_{\mathrm{t}}$-iv & $\begin{array}{l}\text { Sum of semivolatile gases and particles from oxidation of intermediate- } \\
\text { volatility organic compounds }\end{array}$ & \\
\hline OA-iv, $\mathrm{OA}_{\mathrm{p}}$-iv, or $\mathrm{OA}_{\text {particle-iv }}$ & $\begin{array}{l}\text { All particle-phase compounds emitted as intermediate-volatility com- } \\
\text { pounds }\end{array}$ & \\
\hline SV-SOA-V & $\begin{array}{l}\text { Semivolatile secondary organic aerosol emitted as volatile gas precur- } \\
\text { sors (e.g., toluene, high-volatility alkanes, isoprene, } \alpha \text {-pinene) }\end{array}$ & $\begin{array}{l}\text { Volatile - Partitions almost en- } \\
\text { tirely to gas phase at } \\
\text { atmospheric conditions }\end{array}$ \\
\hline LV-SOA-v & Low-volatility products from the aging of traditional SOA compounds & \\
\hline$S V-S O A_{t}-v$ & $\begin{array}{l}\text { Sum of semivolatile gases and particles from oxidation of volatile or- } \\
\text { ganic compounds }\end{array}$ & \\
\hline SV-bSOA-v & $\begin{array}{l}\text { Semivolatile biogenic secondary organic aerosol emitted as volatile gas } \\
\text { precursors (e.g., isoprene, } \alpha \text {-pinene, terpinene, } \beta \text {-caryophyllene) }\end{array}$ & \\
\hline SV-aSOA-v & $\begin{array}{l}\text { Semivolatile anthropogenic secondary organic aerosol emitted as } \\
\text { volatile gas precursors (e.g., toluene, high-volatility alkanes and } \\
\text { alkenes) }\end{array}$ & \\
\hline LV-bbOA-v & $\begin{array}{l}\text { Low-volatility products of oxidation of volatile biomass burning emis- } \\
\text { sions }\end{array}$ & \\
\hline LV-POA & Low-volatility primary organic aerosol & $\begin{array}{l}\text { Unknown volatility at source } \\
\text { (e.g., field measurement) }\end{array}$ \\
\hline $\mathrm{OA}, \mathrm{OA}_{\mathrm{p}}$, or $\mathrm{OA}_{\text {particle }}$ & Total organic aerosol & \\
\hline LV-aSOA & Low-volatility anthropogenic secondary organic aerosol & \\
\hline LV-bbOA & Low-volatility particle-phase compounds from biomass burning & \\
\hline SV-bbPOA & Semivolatile biogenic primary organic aerosol & \\
\hline SV-SOA & Semivolatile SOA & \\
\hline
\end{tabular}

matrix factorization techniques, source attribution combined with knowledge of the volatility distribution could yield a suite of OA classes in need of identification. (2) A series of lab experiments are designed to age several OA precursors of varying carbon number (and thus volatility) in a flow tube. The OA is characterized with a thermodenuder and the resulting OA yields measured during the campaign can be organized using both volatility prefixes (that of the OA produced in the chamber) and suffixes (that of the precursor species). (3) The emissions of a power plant plume can be captured in a portable smog chamber and measured with a $\mathrm{GC} \times \mathrm{GC}$ vacuum ultra-violet high-resolution time-of-flight mass spectrometer to obtain a volatility and polarity distribution. The captured emissions can then be aged inside the 
Table 6. Organic aerosol classifications used in the literature.

\begin{tabular}{llll}
\hline Notation & Reference & Literature definition & Mapping to proposed framework \\
\hline OOA & Jimenez et al. (2009) & Oxygenated organic aerosol & SOA \\
LV-OOA & Jimenez et al. (2009) & Low-volatility OOA with $C^{*} \leq 3.2 \mu \mathrm{g} \mathrm{m}^{-3}$ & LV-SOA \\
SV-OOA & Jimenez et al. (2009) & Semivolatile OOA with $0.01 \leq C^{*} \leq 100 \mu \mathrm{g} \mathrm{m}^{-3}$ & SV-SOA \\
OPOA & Shrivastava et al. (2008) & Oxygenated primary organic aerosol & ELV-SOA-elv + ELV-SOA-lv + ELV-SOA-sv \\
& & & + LV-SOA-elv + LV-SOA-lv + LV-SOA-sv \\
& & & + SV-SOA-elv + SV-SOA-lv + SV-SOA-sv \\
\hline
\end{tabular}

chamber and resampled to observe effects of aging on volatility. The chemical composition information would yield valuable insights on the apportionment of primary vs. secondary $\mathrm{OA}$ and the dependence of this apportionment on initial and final volatility.

\section{Application to source measurement and policy}

Organic aerosol model, field and laboratory results are synthesized and used to inform policy decisions. Conversely, regulations and policy goals are often used to frame scientific inquiry and results (e.g., estimates of anthropogenic environmental impacts with respect to future emission scenarios). Although specific, effective communication within the organic aerosol scientific community is vital, it is likewise important to address the larger community of people interested in air quality. One major point of confusion is the specific definition of primary versus secondary OA. It is now widely understood in the organic aerosol community that the line between primary and secondary OA categories is blurred, especially for semivolatile and intermediate-volatility compounds (Donahue et al., 2009).

Historically, segregation of primary and secondary OA has focused on bulk OA mass, not individual compounds. For example, a typical approach has been to first measure particlephase organic mass directly emitted to the atmosphere from a source, classifying it as primary. Then any detected increase in organic mass downwind from the source has been attributed to secondary OA (presuming therefore that the OA enhancement resulted from oxidation of organic vapors and condensation of some of those products). This analysis assumes that all primary OA mass is inert. Knowing that the dynamic condensation and evaporation of OA compounds does occur, three atmospheric evolution trajectories become difficult to categorize as either primary or secondary OA:

1. Emitted vapor mass condenses to the particle phase, adding mass downwind that has not reacted (SV-POAsv or SV-POA under the proposed framework).

2. Emitted particle-phase mass evaporates, reacts and condenses back to the particle phase, changing the chemical nature of the carbon mass without changing the loading (SV-SOA-sv under the proposed framework).
3. Emitted low-volatility, particle-phase mass reacts in the particle phase. This mass likely never went through a condensation process but changed the chemical nature of the carbon mass without changing the loading (LVSOA-lv under the proposed framework).

The difficulty in the first two examples derives from the error in treating primary OA compounds with the static, inert assumption. The difficulty in the third example results from the conflict between the historical definition of secondary OA - bulk mass (either emitted in the vapor phase or formed from the oxidation of vapor-phase emissions) that, through condensation, has added mass to the particle phase sometime later - and the more chemically precise definition of secondary $\mathrm{OA}$ - compounds in the particle phase that have chemically reacted at least once in the atmosphere.

One option to address these contradictions would be to recommend a simplified nomenclature, replacing the $\mathrm{POA} / \mathrm{SOA}$ paradigm and more precisely reflecting the conceptual models currently adopted by the organic aerosol community. On the other hand, the traditional POA/SOA model has a long history and, in general, adequately emphasizes the importance of atmospheric reactivity, partitioning, and aging that are important from a policy perspective. Thus, we propose to bridge the gap by (1) standardizing the conditions (temperature and organic aerosol concentration) at which primary OA is defined; (2) recommending that, for policy applications, secondary OA follow the historical definition (i.e., it should add mass to the particulate phase, not just be a product of a chemical reaction); and (3) providing a map of the classifications from the detailed framework to these broader definitions (Table 7).

Low-volatility emissions may be controlled with technologies targeting particle-phase capture and are well described as primary OA. At the other end of the spectrum, many VOCs are clearly precursors for secondary OA. Intermediatevolatility and semivolatile species may partition to either the particle or gas-phase depending on the temperature and OA concentration of their surroundings. Given that in Table 2 we have already distinguished SV-OA from IV-OA with a boundary of saturation concentration $\left(C^{*}\right)$ equal to $320 \mu \mathrm{g} \mathrm{m}^{-3}$, we propose defining primary OA as material emitted in the particle phase at an OA concentration $\left(C_{\mathrm{OA}}\right)$ equal to or below $320 \mu \mathrm{g} \mathrm{m}^{-3}$ and $T=298 \mathrm{~K}$. In other words, 
Table 7. Mapping of terms from simplified framework to proposed detailed framework*.

\begin{tabular}{ll}
\hline Detailed framework & Simplified framework \\
\hline ELV-POA-elv & \\
LV-POA-lv & \\
SV-POA-sv & \\
ELV-SOA-elv & \\
LV-SOA-elv & \\
SV-SOA-elv & Primary OA \\
ELV-SOA-lv & \\
LV-SOA-lv & \\
SV-SOA-lv & \\
ELV-SOA-sv & \\
LV-SOA-sv & \\
SV-SOA-sv & \\
\hline ELV-SOA-iv & \\
LV-SOA-iv & \\
SV-SOA-iv & \\
ELV-SOA-v & \\
LV-SOA-v & \\
SV-SOA-v & \\
\hline Boundary between primary and secondary OA is defined at \\
$C_{\text {OA }}=320 \mu$ m m
\end{tabular}

primary OA will consist of compounds partitioning principally to the condensed phase at $320 \mu \mathrm{g} \mathrm{m}^{-3}$ and $298 \mathrm{~K}$. This boundary is somewhat arbitrary but has advantages. It preserves consistency between the traditional conceptual model and the detailed framework proposed here. It is high enough in saturation concentration to capture the vast majority of species partitioning to the particle phase at urban and near-source scales. At a $C_{\mathrm{OA}}$ of $320 \mu \mathrm{g} \mathrm{m}^{-3}, 76$ and $97 \%$ of organic mass with $C^{*}=100$ and $10 \mu \mathrm{g} \mathrm{m}^{-3}$ will partition to the particle phase, respectively, according to absorptive partitioning theory (Donahue et al., 2006). On the other hand, 76 and $97 \%$ of organic mass with $C^{*}=1000$ and $10000 \mu \mathrm{g} \mathrm{m}^{-3}$ will partition to the gas phase, respectively. Use of this proposed boundary achieves an adequate separation consistent with the classifications proposed in this work. The $320 \mu \mathrm{g} \mathrm{m}^{-3}$ cutoff is also high enough to be well characterized by current dilution sampling techniques that have difficulty with measurements at low, ambient-like, loadings. This standardization applies directly to other methods of emissions characterization as well. Observations in traffic tunnels and regression analyses performed at ambient concentrations commonly estimate organic aerosol and vapor emissions. Just as for the dilution methods, these estimates must simultaneously report OA concentration and temperature so that an appropriate volatility can be inferred.

With this standard in place, primary OA can be represented as the sum of all of the OA terms with the suffixes -elv, -lv, and -sv; these are species emitted in the particle phase or formed from the reaction of precursors emitted in the par- ticle phase at $320 \mu \mathrm{g} \mathrm{m}^{-3}$ and $298 \mathrm{~K}$. Secondary OA then comprises species emitted at higher volatility or formed from oxidation of precursors emitted at higher volatility (suffixes -iv and -v). Table 7 explicitly maps terms from the detailed framework to the simplified primary/secondary OA model. There is minimal contribution from intermediate and highvolatility organic compounds to primary particles. Thus, the terms IV-POA and V-POA are absent. In short, although the static conceptual model can be a useful representation for the near-source, short-timescale influence of emissions processes, it is fundamentally flawed from a detailed science point of view and should be avoided in applications requiring physical accuracy.

\section{Conclusions}

We have proposed a naming system for classifying atmospheric organic particle and gas compounds. This system is consistent with general classifications used in many field and laboratory studies, as well as developing model frameworks. Specifically, it is applicable to the current conceptual model of quite dynamic mechanisms by which these particles form and age. By introducing a standardized rule for communicating phase state via subscript, the scheme emphasizes the importance of phase transitions and dynamic interactions observed by the scientific community while maintaining consistency with the terms used to communicate to the policy community. We have chosen a classification system that segregates compounds based on their effective saturation concentration at $298 \mathrm{~K}$. The use of alphabetic prefixes (e.g., ELV-, LV-, SV-, etc.) is standardized in terms of $C^{*}$. We have also added a lowercase suffix to track the volatility of each species when it was emitted. This suffix can be applied to any root term describing the chemical nature of OA (e.g., POA, bbOA, aSOA, etc.) and bridges the gap between the traditional, static view of the POA/SOA system and the more recent, dynamic view which treats evaporation upon dilution and aging of both primary and secondary material.

Because of the observed semivolatile behavior of POA from many emissions sources, it is important to standardize the conditions at which particles will be defined to be primary. We propose this to be at $298 \mathrm{~K}$ and an OA concentration of $320 \mu \mathrm{g} \mathrm{m}^{-3}$. This concentration is a suitable compromise between the low loadings seen at ambient conditions and the higher loadings often encountered when performing source measurements. It also agrees nicely with the proposed division between semivolatile and intermediatevolatility OA. This framework provides a standard for communicating detailed phase, volatility, source, and chemical information to experts and non-experts alike, and will be useful as the field continues to evolve. 
Acknowledgements. This research was supported by the European Research Council Project ATMOPACS (Atmospheric Organic Particulate Matter, Air Quality and Climate Change Studies) (grant agreement 267099), the Marie Curie Actions Incoming Fellowship Programme, and the US EPA STAR program.

Edited by: K. Tsigaridis

\section{References}

Abas, M. R., Oros, D. R., and Simoneit, B. R. T.: Biomass burning as the main source of organic aerosol particulate matter in Malaysia during haze episodes, Chemosphere, 55, 1089-1095, doi:10.1016/j.chemosphere.2004.02.002, 2004.

Ahmadov, R., McKeen, S. A., Robinson, A. L., Bahreini, R., Middlebrook, A. M., de Gouw, J. A., Meagher, J., Hsie, E. Y., Edgerton, E., Shaw, S., and Trainer, M.: A volatility basis set model for summertime secondary organic aerosols over the eastern United States in 2006, J. Geophys. Res., 117, D06301, doi:10.1029/2011jd016831, 2012.

Aiken, A. C., de Foy, B., Wiedinmyer, C., DeCarlo, P. F., Ulbrich, I. M., Wehrli, M. N., Szidat, S., Prevot, A. S. H., Noda, J., Wacker, L., Volkamer, R., Fortner, E., Wang, J., Laskin, A., Shutthanandan, V., Zheng, J., Zhang, R., Paredes-Miranda, G., Arnott, W. P., Molina, L. T., Sosa, G., Querol, X., and Jimenez, J. L.: Mexico city aerosol analysis during MILAGRO using high resolution aerosol mass spectrometry at the urban supersite (T0) Part 2: Analysis of the biomass burning contribution and the non-fossil carbon fraction, Atmos. Chem. Phys., 10, 5315-5341, doi:10.5194/acp-10-5315-2010, 2010.

Alfarra, M. R., Hamilton, J. F., Wyche, K. P., Good, N., Ward, M. W., Carr, T., Barley, M. H., Monks, P. S., Jenkin, M. E., Lewis, A. C., and McFiggans, G. B.: The effect of photochemical ageing and initial precursor concentration on the composition and hygroscopic properties of $\beta$-caryophyllene secondary organic aerosol, Atmos. Chem. Phys., 12, 6417-6436, doi:10.5194/acp12-6417-2012, 2012.

An, W. J., Pathak, R. K., Lee, B.-H., and Pandis, S. N.: Aerosol volatility measurement using an improved thermodenuder: Application to secondary organic aerosol, J. Aerosol Sci., 38, 305314, doi:10.1016/j.jaerosci.2006.12.002, 2007.

Andersson-Sköld, Y. and Simpson, D.: Secondary organic aerosol formation in northern Europe: a model study, J. Geophys. Res., 106, 7357-7374, 2001.

Baltensperger, U., Kalberer, M., Dommen, J., Paulsen, D., Alfarra, M. R., Coe, H., Fisseha, R., Gascho, A., Gysel, M., Nyeki, S., Sax, M., Steinbacher, M., Prevot, A. S. H., Sjögren, S., Weingartner, E., and Zenobi, R.: Secondary organic aerosols from anthropogenic and biogenic precursors, Faraday Discuss., 130, 265-278, doi:10.1039/b417367h, 2005.

Bergström, R., Denier van der Gon, H. A. C., Prévôt, A. S. H., Yttri, K. E., and Simpson, D.: Modelling of organic aerosols over Europe (2002-2007) using a volatility basis set (VBS) framework: application of different assumptions regarding the formation of secondary organic aerosol, Atmos. Chem. Phys., 12, 8499-8527, doi:10.5194/acp-12-8499-2012, 2012.

Blando, J. D. and Turpin, B. J.: Secondary organic aerosol formation in cloud and fog droplets: a literature evaluation of plausibility, Atmos. Environ., 34, 1623-1632, 2000.
Cappa, C. D. and Jimenez, J. L.: Quantitative estimates of the volatility of ambient organic aerosol, Atmos. Chem. Phys., 10, 5409-5424, doi:10.5194/acp-10-5409-2010, 2010.

Carlton, A. G., Turpin, B. J., Altieri, K. E., Seitzinger, S. P., Mathur, R., Roselle, S. J., and Weber, R. J.: CMAQ model performance enhanced when in-cloud secondary organic aerosol is included: comparisons of organic carbon predictions with measurements, Environ. Sci. Technol., 42, 8798-8802, doi:10.1021/Es801192n, 2008.

Chan, A. W. H., Isaacman, G., Wilson, K. R., Worton, D. R., Ruehl, C. R., Nah, T., Gentner, D. R., Dallmann, T. R., Kirchstetter, T. W., Harley, R. A., Gilman, J. B., Kuster, W. C., de Gouw, J. A., Offenberg, J. H., Kleindienst, T. E., Lin, Y. H., Rubitschun, C. L., Surratt, J. D., Hayes, P. L., Jimenez, J. L., and Goldstein, A. H.: Detailed chemical characterization of unresolved complex mixtures in atmospheric organics: Insights into emission sources, atmospheric processing, and secondary organic aerosol formation, J. Geophys. Res.-Atmos., 118, 6783-6796, doi:10.1002/jgrd.50533, 2013.

Chung, S. H. and Seinfeld, J. H.: Global distribution and climate forcing of carbonaceous aerosols, J. Geophys. Res., 107, 4407, doi:10.1029/2001jd001397, 2002.

Crippa, M., Canonaco, F., Slowik, J. G., El Haddad, I., DeCarlo, P. F., Mohr, C., Heringa, M. F., Chirico, R., Marchand, N., Temime-Roussel, B., Abidi, E., Poulain, L., Wiedensohler, A., Baltensperger, U., and Prévôt, A. S. H.: Primary and secondary organic aerosol origin by combined gas-particle phase source apportionment, Atmos. Chem. Phys., 13, 8411-8426, doi:10.5194/acp-13-8411-2013, 2013.

Cubison, M. J., Ortega, A. M., Hayes, P. L., Farmer, D. K., Day, D., Lechner, M. J., Brune, W. H., Apel, E., Diskin, G. S., Fisher, J. A., Fuelberg, H. E., Hecobian, A., Knapp, D. J., Mikoviny, T., Riemer, D., Sachse, G. W., Sessions, W., Weber, R. J., Weinheimer, A. J., Wisthaler, A., and Jimenez, J. L.: Effects of aging on organic aerosol from open biomass burning smoke in aircraft and laboratory studies, Atmos. Chem. Phys., 11, 12049-12064, doi:10.5194/acp-11-12049-2011, 2011.

DeCarlo, P. F., Ulbrich, I. M., Crounse, J., de Foy, B., Dunlea, E. J., Aiken, A. C., Knapp, D., Weinheimer, A. J., Campos, T., Wennberg, P. O., and Jimenez, J. L.: Investigation of the sources and processing of organic aerosol over the Central Mexican Plateau from aircraft measurements during MILAGRO, Atmos. Chem. Phys., 10, 5257-5280, doi:10.5194/acp-10-52572010, 2010.

Donahue, N. M., Robinson, A. L., Stanier, C. O., and Pandis, S. N.: Coupled partitioning, dilution, and chemical aging of semivolatile organics, Environ. Sci. Technol., 40, 2635-2643, doi:10.1021/Es052297c, 2006.

Donahue, N. M., Robinson, A. L., and Pandis, S. N.: Atmospheric organic particulate matter: From smoke to secondary organic aerosol, Atmos. Environ., 43, 94-106, doi:10.1016/j.atmosenv.2008.09.055, 2009.

Donahue, N. M., Henry, K. M., Mentel, T. F., Kiendler-Scharr, A., Spindler, C., Bohn, B., Brauers, T., Dorn, H. P., Fuchs, H., Tillmann, R., Wahner, A., Saathoff, H., Naumann, K.-H., Möhler, O., Leisner, T., Müller, L., Reinnig, M.-C., Hoffmann, T., Salo, K., Hallquist, M., Frosch, M., Bilde, M., Tritscher, T., Barmet, P., Praplan, A. P., DeCarlo, P. F., Dommen, J., Prévôt, A. S. H., and Baltensperger, U.: Aging of biogenic secondary organic aerosol 
via gas-phase $\mathrm{OH}$ radical reactions., P. Natl. Acad. Sci. USA, 109, 13503-13508, doi:10.1073/pnas.1115186109, 2012.

England, G. C., Watson, J. G., Chow, J. C., Zielinska, B., Chang, M. C. O., Loos, K. R., and Hidy, G.M.: Dilution-based emissions sampling from stationary sources: part 1 - compact sampler methodology and performance, JAPCA J. Air Waste Ma., 57, 65-78, 2007.

Ervens, B., Turpin, B. J., and Weber, R. J.: Secondary organic aerosol formation in cloud droplets and aqueous particles (aqSOA): a review of laboratory, field and model studies, Atmos. Chem. Phys., 11, 11069-11102, doi:10.5194/acp-1111069-2011, 2011.

Fast, J., Aiken, A. C., Allan, J., Alexander, L., Campos, T., Canagaratna, M. R., Chapman, E., DeCarlo, P. F., de Foy, B., Gaffney, J., de Gouw, J., Doran, J. C., Emmons, L., Hodzic, A., Herndon, S. C., Huey, G., Jayne, J. T., Jimenez, J. L., Kleinman, L., Kuster, W., Marley, N., Russell, L., Ochoa, C., Onasch, T. B., Pekour, M., Song, C., Ulbrich, I. M., Warneke, C., Welsh-Bon, D., Wiedinmyer, C., Worsnop, D. R., Yu, X.-Y., and Zaveri, R.: Evaluating simulated primary anthropogenic and biomass burning organic aerosols during MILAGRO: implications for assessing treatments of secondary organic aerosols, Atmos. Chem. Phys., 9, 6191-6215, doi:10.5194/acp-9-6191-2009, 2009.

Fed. Regist.: U.S. EPA Method 5, 40 United States Federal Register. Vol. 60, Appendix A, available at http://www.epa.gov/ttnemc01/ promgate/m-05.pdf (last access: 3 April 2014), 371-442, 1971.

Fed. Regist.: Environmental Protection Agency: Methods for measurement of filterable $\mathrm{PM}_{10}$ and $\mathrm{PM}_{2.5}$ and measurement of condensable PM emissions from stationary sources: Methods 201a and 202, United States Federal Register, Vol. 75, No. 244, 80118-80172, 2010.

Fountoukis, C., Racherla, P. N., Denier van der Gon, H. A. C., Polymeneas, P., Charalampidis, P. E., Pilinis, C., Wiedensohler, A., Dall'Osto, M., O'Dowd, C., and Pandis, S. N.: Evaluation of a three-dimensional chemical transport model (PMCAMx) in the European domain during the EUCAARI May 2008 campaign, Atmos. Chem. Phys., 11, 10331-10347, doi:10.5194/acp11-10331-2011, 2011.

Fraser, M. P., Cass, G. R., Simoneit, B. R. T., and Rasmussen, R. A.: Air quality model evaluation data for organics. 4. C2-C36 nonaromatic hydrocarbons, Environ. Sci. Technol., 31, 2356-2367, doi:10.1021/es960980g, 1997.

Fraser, M. P., Cass, G. R., Simoneit, B. R. T., and Rasmussen, R. A.: Air quality model evaluation data for organics. 5. C6-C22 nonpolar and semipolar aromatic compounds, Environ. Sci. Technol., 32, 1760-1770, doi:10.1021/es970349v, 1998.

Fuzzi, S., Andreae, M. O., Huebert, B. J., Kulmala, M., Bond, T. C., Boy, M., Doherty, S. J., Guenther, A., Kanakidou, M., Kawamura, K., Kerminen, V.-M., Lohmann, U., Russell, L. M., and Pöschl, U.: Critical assessment of the current state of scientific knowledge, terminology, and research needs concerning the role of organic aerosols in the atmosphere, climate, and global change, Atmos. Chem. Phys., 6, 2017-2038, doi:10.5194/acp-62017-2006, 2006.

Gaydos, T. M., Pinder, R., Koo, B., Fahey, K. M., Yarwood, G., and Pandis, S. N.: Development and application of a three-dimensional aerosol chemical transport model, PMCAMx, Atmos. Environ., 41, 2594-2611, doi:10.1016/j.atmosenv.2006.11.034, 2007.
Grieshop, A. P., Logue, J. M., Donahue, N. M., and Robinson, A. L.: Laboratory investigation of photochemical oxidation of organic aerosol from wood fires 1: measurement and simulation of organic aerosol evolution, Atmos. Chem. Phys., 9, 1263-1277, doi:10.5194/acp-9-1263-2009, 2009a.

Grieshop, A. P., Donahue, N. M., and Robinson, A. L.: Laboratory investigation of photochemical oxidation of organic aerosol from wood fires 2: analysis of aerosol mass spectrometer data, Atmos. Chem. Phys., 9, 2227-2240, doi:10.5194/acp-9-2227-2009, 2009b.

Griffin, R. J., Cocker, D. R., Flagan, R. C., and Seinfeld, J. H.: Organic aerosol formation from the oxidation of biogenic hydrocarbons, J. Geophys. Res.-Atmos., 104, 3555-3567, 1999.

Hallquist, M., Wenger, J. C., Baltensperger, U., Rudich, Y., Simpson, D., Claeys, M., Dommen, J., Donahue, N. M., George, C., Goldstein, A. H., Hamilton, J. F., Herrmann, H., Hoffmann, T., Iinuma, Y., Jang, M., Jenkin, M. E., Jimenez, J. L., Kiendler-Scharr, A., Maenhaut, W., McFiggans, G., Mentel, Th. F., Monod, A., Prévôt, A. S. H., Seinfeld, J. H., Surratt, J. D., Szmigielski, R., and Wildt, J.: The formation, properties and impact of secondary organic aerosol: current and emerging issues, Atmos. Chem. Phys., 9, 5155-5236, doi:10.5194/acp-9-51552009, 2009.

Hennigan, C. J., Bergin, M. H., Russell, A. G., Nenes, A., and Weber, R. J.: Gas/particle partitioning of water-soluble organic aerosol in Atlanta, Atmos. Chem. Phys., 9, 3613-3628, doi:10.5194/acp-9-3613-2009, 2009.

Hennigan, C. J., Miracolo, M. A., Engelhart, G. J., May, A. A., Presto, A. A., Lee, T., Sullivan, A. P., McMeeking, G. R., Coe, H., Wold, C. E., Hao, W.-M., Gilman, J. B., Kuster, W. C., de Gouw, J., Schichtel, B. A., J. L. Collett Jr., Kreidenweis, S. M., and Robinson, A. L.: Chemical and physical transformations of organic aerosol from the photo-oxidation of open biomass burning emissions in an environmental chamber, Atmos. Chem. Phys., 11, 7669-7686, doi:10.5194/acp-11-7669-2011, 2011.

Henry, K. M. and Donahue, N. M.: Photochemical Aging of $\alpha$-Pinene Secondary Organic Aerosol: Effects of $\mathrm{OH}$ radical sources and photolysis, J. Phys. Chem. A, 116, 5932-5940, 2012.

Hildebrandt, L., Donahue, N. M., and Pandis, S. N.: High formation of secondary organic aerosol from the photo-oxidation of toluene, Atmos. Chem. Phys., 9, 2973-2986, doi:10.5194/acp-92973-2009, 2009.

Hildebrandt, L., Engelhart, G. J., Mohr, C., Kostenidou, E., Lanz, V. A., Bougiatioti, A., DeCarlo, P. F., Prevot, A. S. H., Baltensperger, U., Mihalopoulos, N., Donahue, N. M., and Pandis, S. N.: Aged organic aerosol in the Eastern Mediterranean: the Finokalia Aerosol Measurement Experiment - 2008, Atmos. Chem. Phys., 10, 4167-4186, doi:10.5194/acp-10-4167-2010, 2010.

Hildemann, L. M., Cass, G. R., and Markowski, G. R.: A dilution stack sampler for collection of organic aerosol emissions design, characterization and field-tests, Aerosol Sci. Tech., 10, 193-204, 1989.

Hodzic, A., Jimenez, J. L., Madronich, S., Canagaratna, M. R., DeCarlo, P. F., Kleinman, L., and Fast, J.: Modeling organic aerosols in a megacity: potential contribution of semi-volatile and intermediate volatility primary organic compounds to secondary organic aerosol formation, Atmos. Chem. Phys., 10, 5491-5514, doi:10.5194/acp-10-5491-2010, 2010. 
Huffman, J. A., Docherty, K. S., Aiken, A. C., Cubison, M. J., Ulbrich, I. M., DeCarlo, P. F., Sueper, D., Jayne, J. T., Worsnop, D. R., Ziemann, P. J., and Jimenez, J. L.: Chemically-resolved aerosol volatility measurements from two megacity field studies, Atmos. Chem. Phys., 9, 7161-7182, doi:10.5194/acp-9-71612009, 2009.

Isaacman, G., Worton, D. R., Kreisberg, N. M., Hennigan, C. J., Teng, A. P., Hering, S. V., Robinson, A. L., Donahue, N. M., and Goldstein, A. H.: Understanding evolution of product composition and volatility distribution through in-situ $\mathrm{GC} \times \mathrm{GC}$ analysis: a case study of longifolene ozonolysis, Atmos. Chem. Phys., 11, 5335-5346, doi:10.5194/acp-11-5335-2011, 2011.

Jathar, S. H., Miracolo, M. A., Presto, A. A., Donahue, N. M., Adams, P. J., and Robinson, A. L.: Modeling the formation and properties of traditional and non-traditional secondary organic aerosol: problem formulation and application to aircraft exhaust, Atmos. Chem. Phys., 12, 9025-9040, doi:10.5194/acp-12-90252012, 2012.

Jimenez, J. L., Canagaratna, M. R., Donahue, N. M., Prevot, A. S. H., Zhang, Q., Kroll, J. H., DeCarlo, P. F., Allan, J. D., Coe, H., Ng, N. L., Aiken, A. C., Docherty, K. S., Ulbrich, I. M., Grieshop, A. P., Robinson, A. L., Duplissy, J., Smith, J. D., Wilson, K. R., Lanz, V. A., Hueglin, C., Sun, Y. L., Tian, J., Laaksonen, A., Raatikainen, T., Rautiainen, J., Vaattovaara, P., Ehn, M., Kulmala, M., Tomlinson, J. M., Collins, D. R., Cubison, M. J., Dunlea, E. J., Huffman, J. A, Onasch, T. B., Alfarra, M. R., Williams, P. I., Bower, K., Kondo, Y., Schneider, J., Drewnick, F., Borrmann, S., Weimer, S., Demerjian, K., Salcedo, D., Cottrell, L., Griffin, R., Takami, A., Miyoshi, T., Hatakeyama, S., Shimono, A., Sun, J. Y., Zhang, Y. M., Dzepina, K., Kimmel, J. R., Sueper, D., Jayne, J. T., Herndon, S. C., Trimborn, A. M., Williams, L. R., Wood, E. C., Middlebrook, A. M., Kolb, C. E., Baltensperger, U., and Worsnop, D. R.: Evolution of organic aerosols in the atmosphere, Science, 326, 1525-1529, doi:10.1126/science.1180353, 2009.

Jolleys, M. D., Coe, H., McFiggans, G., Capes, G., Allan, J. D., Crosier, J., Williams, P. I., Allen, G., Bower, K. N., Jimenez, J. L., Russell, L. M., Grutter, M., and Baumgardner, D.: Characterizing the aging and biomass burning organic aerosol by use of mixing ratios: a meta-analysis of four regions, Environ. Sci. Technol., 46, 13093-13102, doi:10.1021/es302386v, 2012.

Kanakidou, M., Seinfeld, J. H., Pandis, S. N., Barnes, I., Dentener, F. J., Facchini, M. C., Van Dingenen, R., Ervens, B., Nenes, A., Nielsen, C. J., Swietlicki, E., Putaud, J. P., Balkanski, Y., Fuzzi, S., Horth, J., Moortgat, G. K., Winterhalter, R., Myhre, C. E. L., Tsigaridis, K., Vignati, E., Stephanou, E. G., and Wilson, J.: Organic aerosol and global climate modelling: a review, Atmos. Chem. Phys., 5, 1053-1123, doi:10.5194/acp-5-1053-2005, 2005.

Karydis, V. A., Tsimpidi, A. P., and Pandis, S. N.: Evaluation of a three-dimensional chemical transport model (PMCAMx) in the eastern United States for all four seasons, J. Geophys. Res.Atmos., 112, D14211, doi:10.1029/2006jd007890, 2007.

Kulmala, M., Asmi, A., Lappalainen, H. K., Baltensperger, U., Brenguier, J.-L., Facchini, M. C., Hansson, H.-C., Hov, Ø., O'Dowd, C. D., Pöschl, U., Wiedensohler, A., Boers, R., Boucher, O., de Leeuw, G., Denier van der Gon, H. A. C., Feichter, J., Krejci, R., Laj, P., Lihavainen, H., Lohmann, U., McFiggans, G., Mentel, T., Pilinis, C., Riipinen, I., Schulz, M.,
Stohl, A., Swietlicki, E., Vignati, E., Alves, C., Amann, M., Ammann, M., Arabas, S., Artaxo, P., Baars, H., Beddows, D. C. S., Bergström, R., Beukes, J. P., Bilde, M., Burkhart, J. F., Canonaco, F., Clegg, S. L., Coe, H., Crumeyrolle, S., D’Anna, B., Decesari, S., Gilardoni, S., Fischer, M., Fjaeraa, A. M., Fountoukis, C., George, C., Gomes, L., Halloran, P., Hamburger, T., Harrison, R. M., Herrmann, H., Hoffmann, T., Hoose, C., Hu, M., Hyvärinen, A., Hõrrak, U., Iinuma, Y., Iversen, T., Josipovic, M., Kanakidou, M., Kiendler-Scharr, A., Kirkevåg, A., Kiss, G., Klimont, Z., Kolmonen, P., Komppula, M., Kristjánsson, J.-E., Laakso, L., Laaksonen, A., Labonnote, L., Lanz, V. A., Lehtinen, K. E. J., Rizzo, L. V., Makkonen, R., Manninen, H. E., McMeeking, G., Merikanto, J., Minikin, A., Mirme, S., Morgan, W. T., Nemitz, E., O’Donnell, D., Panwar, T. S., Pawlowska, H., Petzold, A., Pienaar, J. J., Pio, C., Plass-Duelmer, C., Prévôt, A. S. H., Pryor, S., Reddington, C. L., Roberts, G., Rosenfeld, D., Schwarz, J., Seland, Ø., Sellegri, K., Shen, X. J., Shiraiwa, M., Siebert, H., Sierau, B., Simpson, D., Sun, J. Y., Topping, D., Tunved, P., Vaattovaara, P., Vakkari, V., Veefkind, J. P., Visschedijk, A., Vuollekoski, H., Vuolo, R., Wehner, B., Wildt, J., Woodward, S., Worsnop, D. R., van Zadelhoff, G.-J., Zardini, A. A., Zhang, K., van Zyl, P. G., Kerminen, V.-M., S Carslaw, K., and Pandis, S. N.: General overview: European Integrated project on Aerosol Cloud Climate and Air Quality interactions (EUCAARI) - integrating aerosol research from nano to global scales, Atmos. Chem. Phys., 11, 13061-13143, doi:10.5194/acp11-13061-2011, 2011.

Kulmala, M., Kontkanen, J., Junninen, H., Lehtipalo, K., Manninen, H. E., Nieminen, T., Petäjä, T., Sipilä, M., Schobesberger, S., Rantala, P., Franchin, A., Jokinen, T., Järvinen, E., Äijälä, M., Kangasluoma, J., Hakala, J., Aalto, P. P., Paasonen, P., Mikkilä, J., Vanhanen, J., Aalto, J., Hakola, H., Makkonen, U., Ruuskanen, T., Mauldin, R. L., Duplissy, J., Vehkamäki, H., Bäck, J., Kortelainen, A., Riipinen, I., Kurtén, T., Johnston, M. V, Smith, J. N., Ehn, M., Mentel, T. F., Lehtinen, K. E. J., Laaksonen, A., Kerminen, V.-M., and Worsnop, D. R.: Direct observations of atmospheric aerosol nucleation., Science, 339, 943-946, doi:10.1126/science.1227385, 2013.

Lane, T. E., Donahue, N. M., and Pandis S. N.: Simulating secondary organic aerosol formation using the volatility basis-set approach in a chemical transport model, Atmos. Environ., 42, 7438-7451, 2008.

Lanz, V. A., Alfarra, M. R., Baltensperger, U., Buchmann, B., Hueglin, C., and Prévôt, A. S. H.: Source apportionment of submicron organic aerosols at an urban site by factor analytical modelling of aerosol mass spectra, Atmos. Chem. Phys., 7, 15031522, doi:10.5194/acp-7-1503-2007, 2007.

Lee, B. H., Kostenidou, E., Hildebrandt, L., Riipinen, I., Engelhart, G. J., Mohr, C., DeCarlo, P. F., Mihalopoulos, N., Prevot, A. S. H., Baltensperger, U., and Pandis, S. N.: Measurement of the ambient organic aerosol volatility distribution: application during the Finokalia Aerosol Measurement Experiment (FAME2008), Atmos. Chem. Phys., 10, 12149-12160, doi:10.5194/acp10-12149-2010, 2010.

Lee, S. W.: Fine particulate matter measurement and international standardization for air quality and emissions from stationary sources, Fuel, 89, 874-882, 2010.

Li, X., Wang, S., Duan, L., Hao, J., and Long, Z.: Design of a compact dilution sampler for stationary combus- 
tion sources, JAPCA J. Air. Waste Ma., 61, 1124-1130, doi:10.1080/10473289.2011.604556, 2011.

Lim, Y. B., Tan, Y., Perri, M. J., Seitzinger, S. P., and Turpin, B. J.: Aqueous chemistry and its role in secondary organic aerosol (SOA) formation, Atmos. Chem. Phys., 10, 1052110539, doi:10.5194/acp-10-10521-2010, 2010.

Lipsky, E. M. and Robinson, A. L.: Effects of dilution on fine particle mass and partitioning of semivolatile organics in diesel exhaust and wood smoke, Environ. Sci. Technol., 40, 155-162, doi:10.1021/es050319p, 2005.

Liu, J., Horowitz, L. W., Fan, S., Carlton, A. G., and Levy II, H.: Global in-cloud production of secondary organic aerosols: Implementation of a detailed chemical mechanism in the GFDL atmospheric model AM3, J. Geophys. Res., 117, D15303, doi:10.1029/2012jd017838, 2012.

Loza, C. L., Chhabra, P. S., Yee, L. D., Craven, J. S., Flagan, R. C., and Seinfeld, J. H.: Chemical aging of $m$-xylene secondary organic aerosol: laboratory chamber study, Atmos. Chem. Phys., 12, 151-167, doi:10.5194/acp-12-151-2012, 2012.

Marley, N. A., Gaffney, J. S., Tackett, M., Sturchio, N. C., Heraty, L., Martinez, N., Hardy, K. D., Marchany-Rivera, A., Guilderson, T., MacMillan, A., and Steelman, K.: The impact of biogenic carbon sources on aerosol absorption in Mexico City, Atmos. Chem. Phys., 9, 1537-1549, doi:10.5194/acp-9-1537-2009, 2009.

May, A. A., Presto, A. A., Hennigan, C. J., Nguyen, N. T., Gordon, T. D., and Robinson, A. L.: Gas-particle partitioning of primary organic aerosol emissions: (1) gasoline vehicle exhaust, Atmos. Environ., 77, 128-139, doi:10.1016/j.atmosenv.2013.04.060, 2013a.

May, A. A, Presto, A. A., Hennigan, C. J., Nguyen, N. T., Gordon, T. D., and Robinson, A. L.: Gas-particle partitioning of primary organic aerosol emissions: (2) diesel vehicles., Environ. Sci. Technol., 47, 8288-8296, doi:10.1021/es400782j, 2013b.

Mohr, C., Huffman, J. A., Cubison, M. J., Aiken, A. C., Docherty, K. S., Kimmel, J. R., Ulbrich, I. M., Hannigan, M., and Jimenez, J. L.: Characterization of primary organic aerosol emissions from meat cooking, trash burning, and motor vehicles with highresolution aerosol mass spectrometry and comparison with ambient and chamber observations, Environ. Sci. Technol., 43, 24432449, doi:10.1021/Es8011518, 2009.

Murphy, B. N. and Pandis, S. N.: Exploring summertime organic aerosol formation in the eastern United States using a regionalscale budget approach and ambient measurements, J. Geophys. Res., 115, D24216, doi:10.1029/2010JD014418, 2010.

Murphy, B. N., Donahue, N. M., Fountoukis, C., and Pandis, S. N.: Simulating the oxygen content of ambient organic aerosol with the 2D volatility basis set, Atmos. Chem. Phys., 11, 7859-7873, doi:10.5194/acp-11-7859-2011, 2011

Myriokefalitakis, S., Tsigaridis, K., Mihalopoulos, N., Sciare, J., Nenes, A., Kawamura, K., Segers, A., and Kanakidou, M.: Incloud oxalate formation in the global troposphere: a 3-D modeling study, Atmos. Chem. Phys., 11, 5761-5782, doi:10.5194/acp11-5761-2011, 2011.

Ovadnevaite, J., O'Dowd, C., Dall'Osto, M., Ceburnis, D., Worsnop, D. R., and Berresheim, H.: Detecting high contributions of primary organic matter to marine aerosol: A case study, Geophys. Res. Lett., 38, L02807, doi:10.1029/2010g1046083, 2011.
Pandis, S. N., Wexler, A. S., and Seinfeld, J. H.: Secondary organic aerosol formation and transport: 2 . Predicting the ambient secondary organic aerosol-size distribution, Atmos. Environ., 27, 2403-2416, 1993

Pöschl, U.: Atmospheric aerosols: composition, transformation, climate and health effects., Angew. Chem. Int. Edit., 44, 7520 7540, doi:10.1002/anie.200501122, 2005.

Presto, A. A., Miracolo, M. A., Donahue, N. M., and Robinson, A. L.: Secondary organic aerosol formation from high- $\mathrm{NO}_{\mathrm{x}}$ photooxidation of low volatility precursors: n-Alkanes, Environ. Sci. Technol., 44, 2029-2034, doi:10.1021/Es903712r, 2010.

Presto, A. A., Hennigan, C. J., Nguyen, N. T., and Robinson, A. L.: Determination of volatility distributions of primary organic aerosol emissions from internal combustion engines using thermal desorption gas chromatography mass spectrometry, Aerosol Sci. Tech., 46, 1129-1139, doi:10.1080/02786826.2012.700430, 2012.

Robinson, A. L., Donahue, N. M., Shrivastava, M. K., Weitkamp, E. A., Sage, A. M., Grieshop, A. P., Lane, T. E., Pierce, J. R., and Pandis, S. N.: Rethinking organic aerosols: Semivolatile emissions and photochemical aging, Science, 315, 1259-1262, doi:10.1126/science.1133061, 2007.

Robinson, A. L., Grieshop, A. P., Donahue, N. M., and Hunt, S. W.: Updating the Conceptual Model for Fine Particle Mass Emissions from Combustion Systems, JAPCA J. Air Waste Ma., 60, 1204-1222, doi:10.3155/1047-3289.60.10.1204, 2010.

Russell, L. M., Bahadur, R., and Ziemann, P. J.: Identifying organic aerosol sources by comparing functional group composition in chamber and atmospheric particles, P. Natl. Acad. Sci. USA, 108, 3516-3521, doi:10.1073/pnas.1006461108, 2011.

Saleh, R., Walker, J., and Khlystov, A.: Determination of saturation pressure and enthalpy of vaporization of semi-volatile aerosols: The integrated volume method, J. Aerosol Sci., 39, 876-887, doi:10.1016/j.jaerosci.2008.06.004, 2008.

Salo, K., Hallquist, M., Jonsson, A. M., Saathoff, H., Naumann, K.H., Spindler, C., Tillmann, R., Fuchs, H., Bohn, B., Rubach, F., Mentel, Th. F., Müller, L., Reinnig, M., Hoffmann, T., and Donahue, N. M.: Volatility of secondary organic aerosol during $\mathrm{OH}$ radical induced ageing, Atmos. Chem. Phys., 11, 11055-11067, doi:10.5194/acp-11-11055-2011, 2011.

Schauer, J. J., Rogge, W. F., Hildemann, L. M., Mazurek, M. A., and Cass, G. R.: Source Apportionament of airborne particulate matter using organic components as tracers, Atmos. Environ., 30, 3837-3855, 1996

Schichtel, B. A., Malm, W. C., Bench, G., Fallon, S., McDade, C. E., Chow, J. C., and Watson, J. G.: Fossil and contemporary fine particulate carbon fractions at 12 rural and urban sites in the United States, J. Geophys. Res., 113, D02311, doi:10.1029/2007JD008605, 2008.

Seinfeld, J. H.: Air pollution: A half century of progress, AIChE J., 50, 1096-1108, doi:10.1002/aic.10102, 2004.

Seinfeld, J. H. and Pandis, S. N.: Atmospheric Chemistry and Physics: From Air Pollution to Climate Change, 2nd Edn., John Wiley and Sons, Hoboken, New Jersey, 2006.

Seinfeld, J. H. and Pankow, J. F.: Organic atmospheric particulate material, Annu. Rev. Phys. Chem., 54, 121-40, doi:10.1146/annurev.physchem.54.011002.103756, 2003.

Shrivastava, M. K., Lipsky, E. M., Stanier, C. O., and Robinson, A. L.: Modeling semivolatile organic aerosol mass emissions 
from combustion systems, Environ. Sci. Technol., 40, 26712677, doi:10.1021/es0522231, 2006.

Shrivastava, M. K., Lane, T. E., Donahue, N. M., Pandis, S. N., and Robinson, A. L.: Effects of gas particle partitioning and aging of primary emissions on urban and regional organic aerosol concentrations, J. Geophys. Res.-Atmos., 113, D18301 doi:10.1029/2007jd009735, 2008.

Simoneit, B. R. T., Schauer, J. J., Nolte, C. G., Oros, D. R., Elias, V. O., Fraser, M. P., Rogge, W. F., and Cass, G. R.: Levoglucosan, a tracer for cellulose in biomass burning and atmospheric particles, Atmos. Environ., 33, 173-182, 1999.

Simoneit, B. R. T.: Biomass burning - a review of organic tracers for smoke from incomplete combustion, Appl. Geochem., 17, 129$162,2002$.

Simpson, D., Yttri, K. E., Klimont, Z., Kupiainen, K., Caseiro, A., Gelencsér, A., Pio, C., Puxbaum, H., and Legrand, M.: Modeling carbonaceous aerosol over Europe: Analysis of the CARBOSOL and EMEP EC/OC campaigns, J. Geophys. Res., 112, D23S14, doi:10.1029/2006JD008158, 2007.

Stocker, T. F., Qin, D., Plattner, G.-K., Alexander, L. V., Allen, S. K., Bindoff, N. L., Bréon, F.-M., Church, J. A., Cubasch, U., Emori, S., Forster, P., Friedlingstein, P., Gillett, N., Gregory, J. M., Hartmann, D. L., Jansen, E., Kirtman, B., Knutti, R., Krishna Kumar, K., Lemke, P., Marotzke, J., Masson-Delmotte, V., Meehl, G. A., Mokhov, I. I., Piao, S., Ramaswamy, V., Randall, D., Rhein, M., Rojas, M., Sabine, C., Shindell, D., Talley, L. D., Vaughan, D. G., and Xie, S.-P.: Technical Summary. in: Climate Change 2013: The Physical Science Basis. Contribution of Working Group I to the Fifth Assessment Report of the Intergovernmental Panel on Climate Change editd by: Stocker, T. F., Qin, D., Plattner, G.-K., Tignor, M., Allen, S. K., Boschung, J., Nauels, A., Xia, Y., Bex, V., and Midgley, P. M., Cambridge University Press, Cambridge, UK and New York, NY, USA, 2013.

Strader, R., Lurmann, F., and Pandis, S. N.: Evaluation of secondary organic aerosol formation in winter, Atmos. Environ., 33, 48494863, 1999.

Sullivan, A. P., Weber, R. J., Clements, A. L., Turner, J. R., Bae, M. S., and Schauer, J. J.: A method for on-line measurement of water-soluble organic carbon in ambient aerosol particles: results from an urban site, Geophys. Res. Lett., 31, L13105, doi:10.1029/2004g1019681, 2004.
Szidat, S., Jenk, T. M., Synal, H.-A., Kalberer, M., Wacker, L., Hajdas, I., Kasper-Giebl, A., and Baltensperger, U.: Contributions of fossil fuel, biomass-burning, and biogenic emissions to carbonaceous aerosols in Zurich as traced by 14 C, J. Geophys. Res., 111, D07206, doi:10.1029/2005JD006590, 2006.

Tritscher, T., Dommen, J., DeCarlo, P. F., Gysel, M., Barmet, P. B., Praplan, A. P., Weingartner, E., Prévôt, A. S. H., Riipinen, I., Donahue, N. M., and Baltensperger, U.: Volatility and hygroscopicity of aging secondary organic aerosol in a smog chamber, Atmos. Chem. Phys., 11, 11477-11496, doi:10.5194/acp-1111477-2011, 2011.

Tsimpidi, A. P., Karydis, V. A., Zavala, M., Lei, W., Molina, L., Ulbrich, I. M., Jimenez, J. L., and Pandis, S. N.: Evaluation of the volatility basis-set approach for the simulation of organic aerosol formation in the Mexico City metropolitan area, Atmos. Chem. Phys., 10, 525-546, doi:10.5194/acp-10-525-2010, 2010.

Volkamer, R., Jimenez, J. L., San Martini, F., Dzepina, K., Zhang, Q., Salcedo, D., Molina, L. T., Worsnop, D. R., and Molina, M. J.: Secondary organic aerosol formation from anthropogenic air pollution: Rapid and higher than expected, Geophys. Res. Lett., 33, L17811, doi:10.1029/2006GL026899, 2006.

Wallace, J. M. and Hobbs, P. V.: Atmospheric Science: An Introductory Survey, 2nd Edn., Academic Press, Burlington, 2006.

Zhang, Q., Worsnop, D. R., Canagaratna, M. R., and Jimenez, J. L.: Hydrocarbon-like and oxygenated organic aerosols in Pittsburgh: insights into sources and processes of organic aerosols, Atmos. Chem. Phys., 5, 3289-3311, doi:10.5194/acp-5-32892005, 2005.

Zhang, Q., Jimenez, J. L., Canagaratna, M. R., Allan, J. D., Coe, H., Ulbrich, I., Alfarra, M. R., Takami, A., Middlebrook, A. M., Sun, Y. L., Dzepina, K., Dunlea, E., Docherty, K., Decarlo, P. F., Salcedo, D., Onasch, T., Jayne, J. T., Miyoshi, T., Shimono, A., Hatakeyama, S., Takegawa, N., Kondo, Y., Schneider, J., Drewnick, F., Cottrell, L., Griffin, R. J., Rautiainen, J., Sun, J. Y., and Zhang, Y. M.: Ubiquity and dominance of oxygenated species in organic aerosols in anthropogenicallyinfluenced Northern Hemisphere midlatitudes, Geophys. Res. Lett., 34, L13801, doi:10.1029/2007GL029979, 2007.

Zhang, Q., Jimenez, J. L., Canagaratna, M. R., Ulbrich, I. M., Ng, N. L., Worsnop, D. R., and Sun, Y.: Understanding atmospheric organic aerosols via factor analysis of aerosol mass spectrometry: a review., Anal. Bioanal. Chem., 401, 3045-67, doi:10.1007/s00216-011-5355-y, 2011. 